\title{
Hematological and Clinico-biochemical Characteristics of Leukemia in Fischer 344 Rats
}

\author{
Kazuhito MAEJIMA and Sumi NAGASE* \\ Japan Automobile Research Institute, 2530 Karima, Tsukuba-shi, Ibaraki 305 and \\ *Sasaki Institute, 2-2 Surugadai, Kanda, Chiyoda-ku, Tokyo 101, Japan
}

(Received 18 December 1991/Accepted 19 February 1992)

\begin{abstract}
Seventy-one male and 52 female F 344 rats with leukemia used as controls in the 30 -month inhalation studies were characterized by hematological and clinicobiochemical findings. Hematological findings revealed that the leukocyte count, mean corpuscular volume, and mean corpuscular hemoglobin increased in both sexes of leukemic rats showing profound anemia, while the platelet count, erythrocyte count, hematocrit, and hemoglobin concentration decreased. In these rats, the serum levels of low density lipoprotein, free cholesterol, total bilirubin, blood urea nitrogen, and triglyceride and the activities of glutamic oxalacetic trans aminase, glutamic pyruvic transaminase, creatine phosphokinase, alkaline phosphatase, and lactate dehydrogenase increased markedly and the level of high density lipoprotein, the oxygen partial pressure, and the cholinesterase activity decreased. Clinical signs such as decrease in redness of the eyes, decrease in body weight, abdominal distension, staining of the public region, and debility were seen in most leukemic animals. These clinical signs and hematological and clinico-biochemical findings may be helpful in diagnosis of leukemia in long-term experiments. - KEY WORDS : clinical biochemistry, Fischer 344 rats, hematology, leukemia, spontaneous neoplasm
\end{abstract}

Fischer 344 (F 344) rats have been widely used for toxicological and/or carcinogenic studies since the National Cancer Institute (U. S. A.) laid down guidelines recommending their use for such purposes [3]. Therefore, there are many reports on spontaneous neoplasms in these rats $[1,2,4,10-13]$. Leukemia of F 344 rats, first reported by Moloney [12] and named large granular lymphocytic leukemia (LGL) or mononuclear cell leukemia, is thought to originate spontaneously in the spleen at high incidence in this strain. The incidence of leukemia in aged F 344 rats is usually noted to be about $20 \%$, and was reported by Maekawa to be $8-28 \%$ in males and $10-36 \%$ in females [10]. The incidence of leukemia in control animals of this strain in 30-month inhalation studies in our laboratory $[6-8$, $16,18]$, was $24.3 \%$ in males and $24.0 \%$ in females [19]. However, in spite of the high incidence of spontaneous tumors, there are few reports concerning the hematological and clinico-biochemical features of these leukemic rats $[5,14,15]$.

In 30-month inhalation studies carried out under specific pathogen-free conditions, we obtained data on the blood of 235 males and 234 females of over 78 weeks old of which 71 males and 52 females were diagnosed as having leukemia by histopathological examinations. In this paper, we present the hematological and clinico-biochemical characteristics of leukemia in $\mathrm{F} 344$ rats.

\section{Materials and Methods}

Animals, diets, and housing conditions : The specific pathogen-free $\mathrm{F} 344 / \mathrm{Jcl}$ rats used for 30 -month inhalation studies on the effects of diesel exhaust were obtained from CLEA Japan, Inc. During the experiment, the rats were housed six to a stainless-steel cage ( $28 \times$ 
$18 \times 40 \mathrm{~cm})$ in inhalation chambers which were maintained in an air-conditioned room ( $23 \pm 2$ ${ }^{\circ} \mathrm{C}, 55 \pm 10 \%$ relative humidity), with artificial lighting from $7 \mathrm{AM}$ to $7 \mathrm{PM}$. The animals were provided with sterized food (CE-2, CLEA Japan, Inc.) and tap water from an automatic water system ad libitum. They were acclimatized to these conditions for a week and used at 5 weeks old. Body weights were recorded periodically throughout the experiment [7] .

The environment in the barrier was strictly controlled from the microbiological standpoint to protect the animals from infections and other diseases $[6,17]$. Test for air-borne bacteria and 7 kinds of specific pathogens (Sendai virus, Mycoplasma pulmonis, Tyzzer's organism, Corynebacterium kutscheri, Salmonella typhimurium, Mouse hepatitis virus, and Mouse adenovirus) were made every six months.

Hematology and clinical biochemistry : In this 30 -month inhalation study both carcinogenicity and chronic toxicity were examined. For examination of chronic toxicity, several male and female rats were sacrificed after $6,12,18$, and 24 months, respectively, and all rats that survived until the end of the experiment were also examined. Forty - five hematological and clinico-biochemical parameters were examined in all rats. During the experiment, rats that showed clinical abnormalities, such as decrease in redness of the eyes, decrease in body weight, abdominal distension, staining of the pubic region, or debility were killed and promptly examined.

Before sacrifice, the rats were starved overnight, and then anesthetized with ether and blood was drawn from the abdominal aorta into a heparinized syringe. Part of the sample was used for measurement of blood gases and the remainder was centrifuged to separate the plasma. For hematological analyses, part of the blood sample was supplemented with EDTA-2 $\mathrm{K}$ and stored in a capillary whole blood collector. The rest of the blood sample was centrifuged to separate the serum. Measurements were carried out with a TBA-380 biochemical analyzer, an ELT-8 hematology cell counter, a Corning $158 \mathrm{pH} /$ blood gas analyzer, a Jookoo $\mathrm{Na}-\mathrm{K}$ analyzer and chloride meter, an Atago refractometer, and a Helena auto-scanner flurvis and quick quant III . The parameters measured were: the activities of glutamic oxalacetic transaminase (GOT), glutamic pyruvic transaminase (GPT), lactate dehydrogenase (LDH), creatine phosphokinase (CPK), alkaline phosphatase (ALP), amylase (AMY), cholinesterase (ChE), and leucine aminopeptidase (LAP) and blood urea nitrogen (BUN), creatinine (Cr), total bilirubin (TBil), glucose (Glu), triglyceride (TG), total cholesterol (TCHO), free cholesterol (FCHO), low density lipoprotein (LDL), high density lipoprotein (HDL), phospholipid (PL), calcium (Ca), magnesium $(\mathrm{Mg})$, inorganic phosphorus (IP), sodium $(\mathrm{Na})$, potassium $(\mathrm{K})$, chlorine $(\mathrm{Cl})$, total protein (TP), albumin (Alb), $\alpha_{1}$-globulin $\left(\alpha_{1}-G\right), \quad \alpha_{2}$-globulin $\left(\alpha_{2}-G\right), \quad \alpha_{3}$-globulin $\left(\alpha_{3}-G\right), \quad \beta$-globulin $(\beta-G), \quad \gamma$-globulin $(\gamma-$ $G)$, the erythrocyte count (RBC), leukocyte count (WBC), platelet count (PLT), hematocrit $(\mathrm{Ht})$, hemoglobin concentration $(\mathrm{Hb})$, mean corpuscular volume (MCV), mean corpuscular hemoglobin $(\mathrm{MCH})$, mean corpuscular hemoglobin concentration (MCHC), arterial blood $\mathrm{pH}$ ( $\mathrm{pHa})$, carbon dioxide partial pressure $\left(\mathrm{PaCO}_{2}\right)$, oxygen partial pressure $\left(\mathrm{PaO}_{2}\right)$, bicarbonate $\left(\mathrm{HCO}_{3}-\right)$, the anion gap (A. G.) and body weight at exsanguination (B. W.). The anion gap was calculated as : (sodium + potassium) (chlorine + bicarbonate). Further, details of measurements are given elsewhere $[6,8]$.

After autopsy, representative samples were fixed in $10 \%$ buffered formalin solution for several days. Several slices were routinely cut from fixed organs and lesions, embedded in paraffin, sectioned at $4 \mu \mathrm{m}$ thickness and stained with hematoxylin and eosin. All histopathological examinations were performed by Dr. Yuki Takaki, and Dr. Noriyuki Kuwabara, at the Department of Pathology ( I ), Juntendo University School of Medicine [19].

Criterional ranges of hematological and clinico-biochemical values : The ranges of many hematological and clinico-biochemical values change markedly with age in rats [8], so it is not possible to judge whether values obtained in aged rats are normal or abnormal from the normal ranges in rats of all ages. Therefore, sera were obtained from leukemic rats of 78 weeks old or more were classified by age into three groups $(78 \sim 97,98 \sim 117$, and 118 136 weeks old). The criterional ranges of parameters were taken as the means \pm two standard deviations of values in the non- 
Table 1. Criterional ranges of hematological parameters ${ }^{a}$

\begin{tabular}{ccccc}
\hline Parameter & Sex & & Age (weeks) & \\
\cline { 3 - 4 } & & $78 \sim 97$ & $98 \sim 117$ & $118 \sim 136$ \\
\hline $\mathrm{WBC}$ & $\mathrm{M}$ & $2.8 \pm 1.8$ & $5.0 \pm 4.3$ & $6.5 \pm 9.1$ \\
$\left(\times 10^{3} / \mu \ell\right)$ & $\mathrm{F}$ & $1.4 \pm 1.2$ & $2.2 \pm 1.4$ & $4.5 \pm 11.2$ \\
$\mathrm{RBC}$ & $\mathrm{M}$ & $9.5 \pm 2.9$ & $9.8 \pm 2.9$ & $7.0 \pm 5.7$ \\
$\left(\times 10^{6} / \mu \ell\right)$ & $\mathrm{F}$ & $8.3 \pm 0.7$ & $8.0 \pm 0.9$ & $7.1 \pm 3.7$ \\
$\mathrm{Hb}$ & $\mathrm{M}$ & $16.5 \pm 4.0$ & $16.9 \pm 5.4$ & $12.7 \pm 8.8$ \\
$(\mathrm{~g} / \mathrm{d} \ell)$ & $\mathrm{F}$ & $15.1 \pm 1.0$ & $15.0 \pm 1.2$ & $13.0 \pm 5.3$ \\
$\mathrm{Ht}$ & $\mathrm{M}$ & $63 \pm 17$ & $63 \pm 18$ & $49 \pm 36$ \\
$(\%)$ & $\mathrm{F}$ & $57 \pm 6$ & $55 \pm 4$ & $49 \pm 22$ \\
$\mathrm{MCV}$ & $\mathrm{M}$ & $65 \pm 9$ & $64 \pm 9$ & $68 \pm 26$ \\
$(\mathrm{f} \ell)$ & $\mathrm{F}$ & $70 \pm 2$ & $69 \pm 3$ & $70 \pm 12$ \\
$\mathrm{MCH}$ & $\mathrm{M}$ & $18 \pm 2$ & $17 \pm 1$ & $19 \pm 8$ \\
$(\mathrm{pg})$ & $\mathrm{F}$ & $18 \pm 1$ & $19 \pm 1$ & $19 \pm 5$ \\
$\mathrm{MCHC}$ & $\mathrm{M}$ & $27 \pm 3$ & $27 \pm 7$ & $27 \pm 4$ \\
$(\%)$ & $\mathrm{F}$ & $26 \pm 2$ & $27 \pm 1$ & $27 \pm 4$ \\
$\mathrm{PLT}$ & $\mathrm{M}$ & $590 \pm 212$ & $680 \pm 286$ & $768 \pm 741$ \\
$\left(\times 10^{3} / \mu \ell\right)$ & $\mathrm{F}$ & $617 \pm 184$ & $600 \pm 79$ & $726 \pm 490$ \\
\hline
\end{tabular}

a The ranges shown are the means \pm two standard deviations for non-leukemic rats : $78 \sim 97$ weeks old : 47 males and 35 females, $98 \sim 117$ weeks old: 30 males and 20 females, and 118 136 weeks old : 87 males and 127 females

Table 2. Criterional ranges of clinico-biochemical parameters ${ }^{\mathrm{a}}$ (1)

\begin{tabular}{ccccc}
\hline Parameter & Sex & & Age (weeks) & \\
& & $78 \sim 97$ & $98 \sim 117$ & $118 \sim 136$ \\
\hline $\mathrm{pHa}$ & $\mathrm{M}$ & $7.43 \pm 0.07$ & $7.46 \pm 0.06$ & $7.43 \pm 0.10$ \\
& $\mathrm{~F}$ & $7.44 \pm 0.05$ & $7.47 \pm 0.06$ & $7.44 \pm 0.09$ \\
$\mathrm{PaCO}_{2}$ & $\mathrm{M}$ & $32 \pm 6$ & $34 \pm 8$ & $34 \pm 16$ \\
$\left(\mathrm{mmHg}^{2}\right)$ & $\mathrm{F}$ & $32 \pm 7$ & $34 \pm 8$ & $37 \pm 9$ \\
$\mathrm{PaO}_{2}$ & $\mathrm{M}$ & $100 \pm 19$ & $103 \pm 19$ & $97 \pm 31$ \\
$(\mathrm{mmHg})$ & $\mathrm{F}$ & $102 \pm 19$ & $94 \pm 17$ & $97 \pm 34$ \\
$\mathrm{HCO} 3^{-}$ & $\mathrm{M}$ & $21 \pm 3$ & $24 \pm 4$ & $22 \pm 7$ \\
$(\mathrm{mmol} / \ell)$ & $\mathrm{F}$ & $22 \pm 4$ & $25 \pm 4$ & $24 \pm 6$ \\
$\mathrm{~A} . \mathrm{G}$. & $\mathrm{M}$ & $16 \pm 5$ & $16 \pm 5$ & $14 \pm 12$ \\
$(\mathrm{mEq} / \ell)$ & $\mathrm{F}$ & $16 \pm 6$ & $17 \pm 6$ & $17 \pm 9$ \\
\hline
\end{tabular}

a The ranges shown were calculated as described for Table 1.

leukemic rats ( 47 males and 35 females of $78 \sim$ 97 weeks old, 30 males and 20 females of $98 \sim$ 117 weeks old, and 87 males and 127 females of $118 \sim 136$ weeks old).

\section{Results}

Survival rates, body weights, and microbiological conditions : The survival rates of both sexes in experimental months 18 and 24 were about 95 and $80 \%$, respectively, and the 50 $\%$ survival indices of males and females were similar. Subsequently, the survival rates decreased, being about $30 \%$ after 30 months. The body weights increased until 78 weeks in males and 96 weeks in females, and then decreased gradually. Air-borne bacteria in the barrier gave less than three colonies/plate/hour during the test period. Scarcely any air-borne bacteria were detected in the inhalation rooms with inhalation chambers, and serological tests showed that the animals remained pathogenfree throughout the experiment.

Incidences and clinical signs of leukemia : 
Table 3. Criterional ranges of clinico-biochemical parameters ${ }^{\mathrm{a}}$

(2)

\begin{tabular}{|c|c|c|c|c|}
\hline \multirow{2}{*}{ Parameter } & \multirow{2}{*}{ Sex } & \multicolumn{3}{|c|}{ Age (weeks) } \\
\hline & & $78 \sim 97$ & $98 \sim 117$ & $118 \sim 136$ \\
\hline GOT & M & $142 \pm 111$ & $107 \pm 92$ & $200 \pm 316$ \\
\hline$(\mathrm{IU} / \ell)$ & $\mathrm{F}$ & $167 \pm 165$ & $102 \pm 100$ & $187 \pm 185$ \\
\hline GPT & M & $54 \pm 42$ & $30 \pm 28$ & $45 \pm 91$ \\
\hline$(\mathrm{IU} / \ell)$ & $\mathrm{F}$ & $69 \pm 67$ & $40 \pm 38$ & $55 \pm 53$ \\
\hline LDH & M & $334 \pm 268$ & $233 \pm 186$ & $221 \pm 188$ \\
\hline$(\mathrm{IU} / \ell)$ & $\mathrm{F}$ & $294 \pm 278$ & $202 \pm 130$ & $295 \pm 330$ \\
\hline $\mathrm{CPK}$ & M & $58 \pm 23$ & $53 \pm 32$ & $69 \pm 59$ \\
\hline$(\mathrm{IU} / \ell)$ & $\mathrm{F}$ & $50 \pm 21$ & $48 \pm 15$ & $84 \pm 82$ \\
\hline ALP & M & $168 \pm 50$ & $148 \pm 61$ & $269 \pm 267$ \\
\hline$(\mathrm{IU} / \ell)$ & $\mathrm{F}$ & $127 \pm 54$ & $99 \pm 60$ & $213 \pm 211$ \\
\hline LAP & M & $26 \pm 7$ & $26 \pm 5$ & $22 \pm 13$ \\
\hline$(\mathrm{IU} / \ell)$ & $\mathrm{F}$ & $28 \pm 7$ & $25 \pm 4$ & $24 \pm 11$ \\
\hline ChE & M & $1,252 \pm 580$ & $2,046 \pm 822$ & $1,824 \pm 1,821$ \\
\hline$(\mathrm{IU} / \ell)$ & $\mathrm{F}$ & $4,771 \pm 1,074$ & $4,309 \pm 648$ & $2,894 \pm 2,258$ \\
\hline AMY & M & $1,179 \pm 234$ & $1,100 \pm 274$ & $1,184 \pm 582$ \\
\hline$(\mathrm{U} / \mathrm{d} \ell)$ & $\mathrm{F}$ & $1,136 \pm 334$ & $1,240 \pm 346$ & $1,407 \pm 1,044$ \\
\hline
\end{tabular}

a The ranges shown were calculated as described for Table 1 .

Table 4. Criterional ranges of clinico-biochemical parameters ${ }^{\mathbf{a}}$ (3)

\begin{tabular}{ccccc}
\hline Parameter & Sex & & Age (weeks) & \\
\cline { 3 - 4 } & & $78 \sim 97$ & $98 \sim 117$ & $118 \sim 136$ \\
\hline BUN & M & $16 \pm 5$ & $16 \pm 5$ & $27 \pm 21$ \\
(mg/d $\ell)$ & $\mathrm{F}$ & $15 \pm 4$ & $13 \pm 3$ & $18 \pm 16$ \\
$(\mathrm{mg} / \mathrm{d} \ell)$ & $\mathrm{M}$ & $0.7 \pm 0.2$ & $0.7 \pm 0.2$ & $0.9 \pm 0.6$ \\
$\mathrm{TBil}$ & $\mathrm{F}$ & $0.7 \pm 0.1$ & $0.7 \pm 0.1$ & $0.8 \pm 0.2$ \\
$(\mathrm{mg} / \mathrm{d} \ell)$ & $\mathrm{M}$ & $0.3 \pm 0.2$ & $0.3 \pm 0.2$ & $0.4 \pm 0.3$ \\
$\mathrm{Glu}$ & $\mathrm{F}$ & $0.2 \pm 0.1$ & $0.2 \pm 0.1$ & $0.4 \pm 0.3$ \\
$(\mathrm{mg} / \mathrm{d} \ell)$ & $\mathrm{M}$ & $182 \pm 45$ & $168 \pm 40$ & $146 \pm 94$ \\
$\mathrm{Ca}$ & $\mathrm{F}$ & $176 \pm 57$ & $176 \pm 44$ & $152 \pm 79$ \\
$(\mathrm{mg} / \mathrm{d} \ell)$ & $\mathrm{M}$ & $10 \pm 1$ & $11 \pm 1$ & $11 \pm 3$ \\
$\mathrm{Mg}$ & $\mathrm{F}$ & $10 \pm 1$ & $11 \pm 1$ & $11 \pm 2$ \\
$(\mathrm{mg} / \mathrm{d} \ell)$ & $\mathrm{M}$ & $2.5 \pm 0.4$ & $2.4 \pm 0.4$ & $3.0 \pm 1.1$ \\
$\mathrm{IP}$ & $\mathrm{F}$ & $2.6 \pm 0.8$ & $2.4 \pm 0.9$ & $2.8 \pm 1.2$ \\
$(\mathrm{mg} / \mathrm{d} \ell)$ & $\mathrm{M}$ & $5 \pm 2$ & $4 \pm 1$ & $5 \pm 5$ \\
$\mathrm{Na}$ & $\mathrm{F}$ & $5 \pm 2$ & $5 \pm 2$ & $5 \pm 3$ \\
$(\mathrm{mEq} / \ell)$ & $\mathrm{M}$ & $144 \pm 3$ & $145 \pm 3$ & $141 \pm 8$ \\
$\mathrm{~K}$ & $\mathrm{~F}$ & $146 \pm 6$ & $144 \pm 3$ & $141 \pm 6$ \\
$(\mathrm{mEq} / \ell)$ & $\mathrm{M}$ & $3.8 \pm 0.5$ & $3.9 \pm 0.6$ & $4.1 \pm 1.0$ \\
$\mathrm{Cl}$ & $\mathrm{F}$ & $3.5 \pm 0.5$ & $3.5 \pm 0.5$ & $3.6 \pm 0.9$ \\
$(\mathrm{mEq} / \ell)$ & $\mathrm{M}$ & $111 \pm 6$ & $108 \pm 4$ & $107 \pm 10$ \\
\hline $\mathrm{T}$ & $\mathrm{F}$ & $110 \pm 6$ & $106 \pm 4$ & $105 \pm 7$ \\
\hline
\end{tabular}

a The ranges shown were calculated as described for Table 1 .

Leukemia was the most frequent malignant tumor, its incidence being $24.3 \%$ in males and $24.0 \%$ in females of all ages in 30 -month inhalation studies and $30.2 \%$ in the cases in males and $22.2 \%$ of those in females were diagnosed from blood date. The numbers of leukemic rats diagnosed from blood data in the three age groups were as follows; $78 \sim 97$ 
Table 5. Criterional ranges of clinico-biochemical parameters ${ }^{\mathrm{a}}$ (4)

\begin{tabular}{ccrcc}
\hline & & \multicolumn{3}{c}{ Age (weeks) } \\
\cline { 3 - 5 } Parameter & Sex & $78 \sim 97$ & $98 \sim 117$ & $118 \sim 136$ \\
\hline $\mathrm{TG}$ & $\mathrm{M}$ & $57 \pm 36$ & $55 \pm 28$ & $201 \pm 199$ \\
$(\mathrm{mg} / \mathrm{d} \ell)$ & $\mathrm{F}$ & $56 \pm 29$ & $74 \pm 53$ & $228 \pm 225$ \\
$\mathrm{TCHO}$ & $\mathrm{M}$ & $75 \pm 34$ & $88 \pm 61$ & $110 \pm 108$ \\
$(\mathrm{mg} / \mathrm{d} \ell)$ & $\mathrm{F}$ & $110 \pm 34$ & $135 \pm 62$ & $169 \pm 141$ \\
$\mathrm{FCHO}$ & $\mathrm{M}$ & $15 \pm 12$ & $21 \pm 19$ & $37 \pm 34$ \\
$(\mathrm{mg} / \mathrm{d} \ell)$ & $\mathrm{F}$ & $26 \pm 12$ & $33 \pm 24$ & $50 \pm 48$ \\
$\mathrm{LDL}$ & $\mathrm{M}$ & $27 \pm 15$ & $31 \pm 16$ & $63 \pm 60$ \\
$(\mathrm{mg} / \mathrm{d} \ell)$ & $\mathrm{F}$ & $22 \pm 11$ & $27 \pm 18$ & $97 \pm 95$ \\
$\mathrm{HDL}$ & $\mathrm{M}$ & $68 \pm 29$ & $71 \pm 51$ & $72 \pm 70$ \\
$(\mathrm{mg} / \mathrm{d} \ell)$ & $\mathrm{F}$ & $109 \pm 44$ & $128 \pm 52$ & $131 \pm 128$ \\
$\mathrm{PL}$ & $\mathrm{M}$ & $132 \pm 50$ & $164 \pm 94$ & $224 \pm 215$ \\
$(\mathrm{mg} / \mathrm{d} \ell)$ & $\mathrm{F}$ & $226 \pm 70$ & $296 \pm 130$ & $356 \pm 266$ \\
\hline
\end{tabular}

a The ranges shown were calculated as described for Table 1 .

Table 6. Criterional ranges of clinicco-biochemical parameters ${ }^{a}$

(5)

\begin{tabular}{ccccc}
\hline Parameter & Sex & & Age (weeks) & \\
\cline { 3 - 4 } & & $78 \sim 97$ & $698 \sim 117$ & $118 \sim 136$ \\
\hline TP & $\mathrm{M}$ & $6.0 \pm 0.6$ & $6.1 \pm 0.6$ & $5.8 \pm 1.4$ \\
(g/d $\ell)$ & $\mathrm{F}$ & $7.0 \pm 1.0$ & $7.2 \pm 0.8$ & $6.9 \pm 2.0$ \\
Alb & $\mathrm{M}$ & $52 \pm 11$ & $49 \pm 9$ & $39 \pm 16$ \\
$(\%)$ & $\mathrm{F}$ & $55 \pm 6$ & $48 \pm 15$ & $42 \pm 16$ \\
$\alpha_{1}-\mathrm{G}$ & $\mathrm{M}$ & $19 \pm 9$ & $19 \pm 5$ & $23 \pm 14$ \\
$(\%)$ & $\mathrm{F}$ & $18 \pm 7$ & $22 \pm 16$ & $24 \pm 15$ \\
$\alpha_{2}-\mathrm{G}$ & $\mathrm{M}$ & $3 \pm 1$ & $5 \pm 2$ & $5 \pm 3$ \\
$(\%)$ & $\mathrm{F}$ & $3 \pm 1$ & $5 \pm 3$ & $6 \pm 4$ \\
$\alpha_{3}-\mathrm{G}$ & $\mathrm{M}$ & $4 \pm 2$ & $4 \pm 1$ & $4 \pm 2$ \\
$(\%)$ & $\mathrm{F}$ & $4 \pm 1$ & $4 \pm 2$ & $4 \pm 2$ \\
$\beta-\mathrm{G}$ & $\mathrm{M}$ & $18 \pm 5$ & $19 \pm 4$ & $20 \pm 8$ \\
$(\%)$ & $\mathrm{F}$ & $15 \pm 3$ & $15 \pm 3$ & $16 \pm 7$ \\
$\gamma-\mathrm{G}$ & $\mathrm{M}$ & $6 \pm 4$ & $8 \pm 4$ & $11 \pm 7$ \\
$(\%)$ & $\mathrm{F}$ & $7 \pm 3$ & $8 \pm 4$ & $8 \pm 5$ \\
B. W. & $\mathrm{M}$ & $212 \pm 58$ & $365 \pm 48$ & $303 \pm 87$ \\
$(\mathrm{~g})$ & $\mathrm{F}$ & $224 \pm 56$ & $242 \pm 42$ & $250 \pm 68$ \\
\hline
\end{tabular}

a The ranges shown were calculated as described for Table 1 .

weeks old : 6 males and 8 females; 98 117 weeks old : 17 males and 10 females, and 118 136 weeks old : 48 males and 34 females.

Decrease in redness of the eyes, decrease in body weight, abdominal distension, staining of the pubic region, and debility were observed in $75 \%, 70 \%, 66 \%, 32 \%$, and $62 \%$ of 71 males with leukemia and in 65\%, 49\%, 69\%, 18\%, and $53 \%$ of 52 females with leukemia. The serum was deep yellow in 55\% of the males and $41 \%$ of the females.
Hematological and clinico-biochemical findings : The criterional ranges of the 45 parameters are shown in Tables 1-6. Fig. 1 show the frequency distributions of LDL values of the males and $\mathrm{Hb}$ values of the females with leukemia in three age groups. The proportions of animals deviated from the criterional range of each parameters in these rats are summarized in Fig. 2. Of the males with leukemia increased values were observed for LDL in $77 \%$ (Fig. 1), the WBC in $73 \%$, FCHO in $63 \%$, ALP 

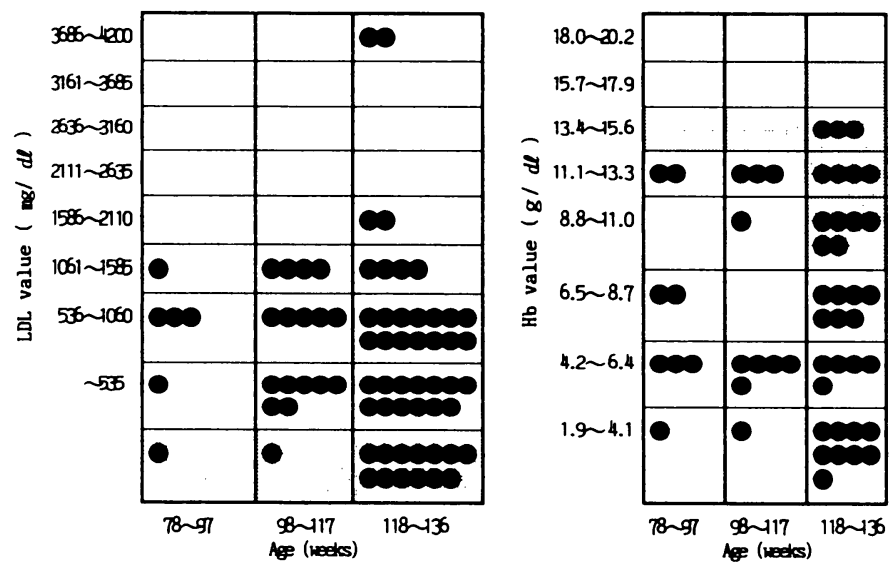

Fig. 1. Frequency distributions of LDL values of the males (left) and $\mathrm{Hb}$ values of the females (right) with leukemia in three age groups $\square$ : criterional ranges LDL ; 78 97:27 $\pm 15(\mathrm{mg} / \mathrm{d} l) 98 \sim 117: 31 \pm 16(\mathrm{mg} / \mathrm{d} l) 118 \sim 136: 63 \pm 60(\mathrm{mg} /$ $\mathrm{d} l) \mathrm{Hb}: 78 \sim 97: 15.1 \pm 1.0(\mathrm{~g} / \mathrm{d} l) 98 \sim 117: 15.0 \pm 1.2(\mathrm{~g} / \mathrm{d} l)$ $118 \sim 136: 13.0 \pm 5.3(\mathrm{~g} / \mathrm{d} l)$

in 56\%, GOT in 56\%, TBil in 55\%, CPK in 46 $\%, \mathrm{LDH}$ in $48 \%$, the $\mathrm{MCV}$ in $44 \%$, BUN in 42 $\%$, the $\mathrm{MCHC}$ in $41 \%$, and $\mathrm{TG}$ in $41 \%$, and decreased values for the $\mathrm{Ht}$ in $45 \%$, the $\mathrm{RBC}$ in $44 \%, \mathrm{ChE}$ in $41 \%$, and $\mathrm{Hb}$ in $42 \%$. No definite change in LAP was observed.

On the females, increased values were observed for the WBC in $76 \%$, TBil in $71 \%$, LDL in $65 \%$, the $\mathrm{MCH}$ in $65 \%$, GOT in $65 \%$, $\mathrm{LDH}$ in $61 \%$, CPK in $61 \%, \mathrm{FCHO}$ in $59 \%$, the MCV in $53 \%$, and ALP in $50 \%$, and decreased values for $\mathrm{Hb}$ in $73 \%$ (Fig. 1), the $\mathrm{RBC}$ in $65 \%$, the $\mathrm{Ht}$ in $61 \%$, the PLT in $53 \%, \mathrm{ChE}$ in $51 \%$, and HDL in $43 \%$. No marked differences were observed in the values for other parameters in leukemic and non-leukemic rats.

\section{Discussion}

There are many histological reports on naturally occurring neoplastic and nonneoplastic lesions in F 344 rats, but few on the hematological and clinico-biochemical features of F 344 rats with leukemia. Clinical signs, such as decrease in redness of the eyes, decrease in body weight, abdominal distension, staining of the pubic region, debility, and deep yellow serum were observed in most leukemic animals. These signs may be due to anemia, hypertrophy of the spleen, urobilinogen in the urine, and bilirubin in the serum, respectively. Splenomegaly or hepatosplenomegaly was also observed in leukemic rats. Enlargement of the lymph nodes was not prominent, although systemic enlargement of the lymph nodes was detected in a few cases. Histologically, infiltration of leukemic cells into the spleen or liver was seen, and some cases also showed cellular infiltration into the lymph nodes, lungs, bone marrow, gastrointestinal tracts, kidneys, adrenal glands, and brain. Infiltration of leukemic cells into the liver was occasionally found, even when splenomegaly was not seen [19].

In both sexes, the hematological and clinico-biochemical characteristics of leukemia were increases in the leukocyte count, total bilirubin, low density lipoprotein, free cholesterol, glutamic oxalacetic transaminase, mean corpuscular hemoglobin, alkaline phosphatase, the mean corpuscular volume, lactate dehydrogenase, creatine phosphokinase, blood urea nitrogen, triglyceride, and glutamic pyruvic transaminase, and decreases in the erythrocyte count, hemoglobin concentration, hematocrit, platelet count, cholinesterase, high density lipoprotein, and oxygen partial pressure. Of the animals sacrificed during the experiment because they showed abnormalities, $70 \%$ of the males and $80 \%$ of the females were diagnosed 


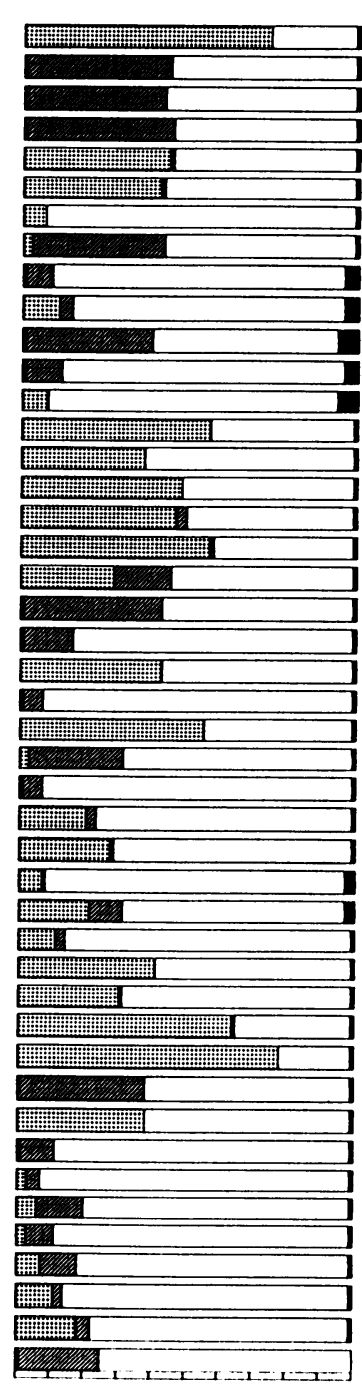

0102030405060708090100 (q)

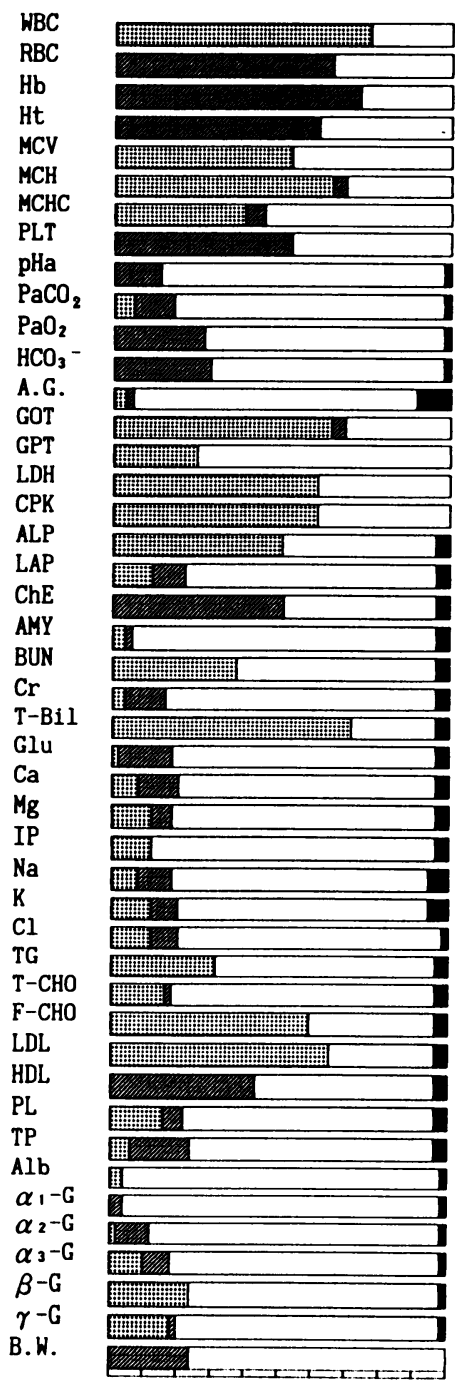

$0102030405060708090100(x)$

Fig. 2. Proportions of leukemic rats of both sexes with values deviating from the criterional ranges (males: left, females : right) $\mathbf{E D}^{\mathrm{W}}$ : increase $\square$ : decrease $\square$ : within criterional range $\boldsymbol{m}$ : not determined

to have leukemia because of deviations of more than 10 parameters from the criterional ranges. However, the early stage of leukemia could not be diagnosed in this way. Hematological studies revealed that leukemic rats were markedly anemic compared with nonleukemic rats and that anemia correlated well with the clinical sign of decrease in redness of the eyes. Increased serum levels of low density lipoprotein, free cholesterol, glutamic oxalacetic transaminase, glutamic pyruvic transaminase, lactate dehydrogenase and alkaline phosphatase and reduced levels of high density lipoprotein and cholinesterase indicated both hepatocellular injury and cholestasis [5]. Increased levels of total bilirubin, blood urea nitrogen, and creatine phosphokinase suggested hemolysis, reduction of kidney func- 
tion, and injury of the heart, respectively. A reduced oxygen partial pressure might reflect general debilitation.

Stromberg et al. $[14,15]$ reported in depth the hematological and clinico-biochemical deviations from the normal found in the leukemic F 344 rats. These papers, however, did not break down the results into males vs. females or specifically defined age groups.

Most of the rats in this study had several tumors [19], so the results obtained may not exactly reflect the leukemic state. However, in long-term experiments, multiple primary tumors in various organs, such as the pituitary gland, mammary gland, and adrenal gland in individual rats were relatively common. Therefore, in practice, these clinical signs and hematological and clinico-biochemical findings may be helpful in diagnosis of leukemia in long-term experiments.

\section{References}

[1] Davey, F. R. and Moloney, W. C. (1970). Postmortem observations on Fischer rats with leukemia and other disorders. Lab. Invest., 23, 327-334.

[2] Goodman, D. G., Ward, J. M., Squire, R. A., Chu, K. C., and Linhart, M.S. (1979). Neoplastic and nonneoplastic lesions in aging F 344 rats. Toxicol Appl Fharmacol, 48, 237-248.

[3] Guidelines for carcinogen bioassay in small rodents. (1974). Carcinogenesis Bioassay Program, Division of Cancer Control and Prevention. NCI, Bethesda, Md.

[4] Jacobs, B. B. and Huseby, R. A. (1967). Neoplasms occurring in aged Fischer rats, with special reference to testicular, uterine, and thyroid tumors. J. Nat. Cancer Inst., 39, 303-309.

[5] Kusewitt, D. F., Hahn, F. F., and Pickrell, J. A. (1982). Hematologic and serum chemical characteristics of mononuclear leukemia in Fischer 344 rats. Lab. Animal Sci, 32, 275-277.

[6] Maejima, K. and Nagase, S. (1989). Hematological and clinico-biochemical studies on F 344 rats inhaled diesel engine exhaust. In Man and his Ecosystem, 2 : pp 149-154, Brasser, L. J. and Mulder, W. C. (eds.), Elsevier, Amsterdam.

[7] Maejima, K. and Takahashi, H. (1990). Study on the water intake of rat during long-term inhalation of diesel exhaust. Exp. Anim, 39, 81-88 (in Japanese with English summary).

[8] Maejima, K. and Nagase, S. (1990). An evaluation method for hematological and clinico-biochemical ralues in aged F 344 rats on chronic toxicity tests such as long-term inhalation studies on the effects of diesel exhaust. Exp. Anim, 39, 213-222 (in Japanese with English summary)

[9] Maejima, K. and Nagase, S. (1991). Effects of starvation and refeeding on the circadian rhythms of hematological and clinico-biochemical values, and water intake of rats. Exp. Anim, 40, 389-393.

[10] Maekawa, A. (1990). Characteristics of F 344 rats in a stand-point of naturally occurring neoplastic and non-neoplastic lesions. Exp. Anim, 39, 507-517 (in Japanese).

[11] Maekawa, A., Kurokawa, Y., Takahashi, M., Kokubo, T., Ogiu, T., Onodera, H., Tanigawa, H., Ohno, Y., Furukawa, F., and Hayashi, Y (1983). Spontaneous tumors in F $344 /$ DuCrj rats. Gann, 74, 365-372.

[12] Moloney, W. C., Boschetti, A. E., and King, V. P. (1970). Spontaneous leukemia in Fischer rats. Cancer Res., 30, 41-43.

[13] Sass, B., Rabstein, L. S., Madison, R., Nims, R.M., Peters, R L, and Kellof, G. J. (1975). Incidence of spontaneous neoplasms in $\mathrm{F} 344$ rats throughout the natural lifespan $J$. Natl. Cancer Inst., 54, 1449-1456

[14] Stromberg, P. C., Vogtsberger, L . M , Marsh, L. R., and Wilson, F. D. (1983). Pathology of the mononuclear cell leukemia of Fischer rats. II . Hematology. Vet. Pathol, 20, 709-717.

[15] Stromberg, P. C , Vogtsberger, L. M., and Marsh, L. R. (1983). Pathology of the mononuclear cell leukemia of Fischer rats. II . Clinical chemistry. Vet. Pathol, 20, 718-726.

[16] Suzuki, T., Nakajima, T., Maejima K., Kato, A., Takaki, Y , Kuwabara, N., Hisanaga, A., and Ishinishi, N. (1990). Long-term inhalation experiments on the health effects of diesel exhaust-the findings on F-344 rats in carcinogenicity experiment in terms of dose-response relationship-. J. Japan Soc. Air Pollut., 25, 192-205 (in Japanese with English summary).

[17] Suzuki, T., Nakajima, T., Sueyoshi, Y., and Ito, T. (1985). Animal exposure facility for diesel engine exhaust emission. J. Japan Automo. Res. Inst., 7, 238-241 (in Japanese).

[18] Takaki, Y., Kitamura, S., Kuwabara, N., and Fukuda, Y. (1989). Long-term inhalation studies of exhaust from the diesel engine in $F 344$ rats : the quantitative relationship between pulmonary hyperplasia and anthracosis. Exp. Pathol. 37, 56-61.

[19] Takaki, Y., Kitamura, S., Uekusa, T., Honma, S., Aze, Y., Wakabayashi, K., Kuwabara, N., and Fukuda, Y. (1989). Spontaneous tumors in F $344 / \mathrm{Jcl}$ rats. J. Toxicol Sci, 14, 181-195. 


\section{白血病 Fischer 344 ラットの血液学的・ 臨床生化学的特徵}

前島一亿・長瀬すみ*

財団法人日本自動車研究所第一研究部

*財団法人佐々木研究所

F 344 ラットを用いた長期吸入実験（30カ月）におい て，実験対照群の中で白血病と診断された雄71匹，集52 匹の血液学的・臨床生化学的值を非白血病ラットのそれ と比較した。その結果, 白血病ラットは非白血病ラット に比べ, 赤血球, へモグロビン，へマトクリット，血小 板が减少し重度の負血を示したが，白血球，平均赤血球 容積, 平均赤血球色素量は増加した。さらに，血清中の 低比重リポタンパク，遊離コレステロール，総ビリルビ ン, 尿素窒素, トリグリセリドおよび GOT, GPT, クレ
アチンホスフォキナーゼ, アルカリ性ホスファターゼ, 乳酸脱水素酵素活性などの高值と高比重りポタンパク, 酸素分圧, コリンェステラーゼ活性などの低值を示し た。また, 白血病ラットの臨床観察では, 目の赤みの薄 れ, 体重減少, 腹部の膨満, 陰部の污れおよび衰弱など がみられた。これら臨床観察および血液性状の特徵は， 長期動物実験におけるラット白血病の診断に有効な判断 基準になりらると考えられる。 